\title{
Boundaries of Belonging: Sino-Indian Relations and the 1960 Tibetan Muslim Incident
}

\section{DAVID G. ATWILL}

Bridging Tibetan, Chinese, and South Asian studies, this article examines the 1960 Tibetan Muslim Incident, when nearly one thousand Tibetan Muslims declared themselves to be Indian citizens by virtue of their Kashmiri ancestry and petitioned the Chinese government to be allowed to emigrate to India. The paradox of the 1960 Tibetan Muslim Incident is that it occurred after a decade of careful Sino-Indian diplomacy, a diplomacy emerging out of each nation's shared struggle for independence and liberation from an anti-imperialist past. By locating the event in the broader ideological movements of postcolonial Asia, the article focuses on a set of aspirations, motivations, and spaces by which China, India, and the Tibetan Muslims sought to define their actions outside of standard nationalistic, ideological, and military narratives of the period.

$\mathrm{O}$ N August 12, 1959, the New York Times ran an article with the provocative headline "India's Traders Held by Chinese." In the retaliatory Cold War logic of the period, most readers would have seen the People's Republic of China's actions as part of a much larger tableau of military and political events. Only months earlier, a series of uprisings had precipitated the Dalai Lama's flight from Tibet, triggering a massive uprising in Lhasa that was swiftly suppressed by the Chinese, and caused tens of thousands of Tibetan refugees to flee to India. However, as the article was quick to point out, the detained individuals were not, as one might have expected, Indian nationals simply caught out by the abruptly shifting political winds. Nor were the five "Indian traders" unequivocally Indian citizens. Described by the Indian government as "Kashmiri Muslims," the group arrested by the Chinese were part of a community that had resided in Tibet for generations, and by their own admission had "never carried [Indian] travel documents and identification certificates," even though they "wanted to register themselves as Indian Nationals" (New York Times 1959). ${ }^{1}$

\footnotetext{
David G. Atwill (dgatwill@psu.edu) is Associate Professor of History at Pennsylvania State University.

${ }^{1}$ By "Tibet," I am not limiting myself to the Chinese administrative region of the Tibetan Autonomous Region, only formally established in 1965, nor to the bounds of the Dalai Lama's political reach (e.g., "political" Tibet). As Richardson (1984), Tan (2013), and others have suggested, Tibet "operated on a far more diverse political basis than simple allegiance to the rule of Lhasa" (Tan 2013). As such, by "Tibet" I am referring to the topographical region of the Tibetan plateau overlaid with the three Tibet regions of Amdo, Kham, and Ü-Tsang. While acknowledging that no word in premodern Tibetan comfortably glosses the modern ethnonym "Tibetan" and that Goldstein (1997, x-xi) and others have pointed out that "Tibet" is an amorphous and contested
} 
As would become clearer in the coming weeks and months, the imprisoned individuals held by the Chinese were members of Lhasa's several thousand-strong Tibetan Muslim community known as Khache (Tib. khaché). In its earliest formulation, the Tibetan word "Khache," discussed in more detail below, referred to the Himalayan region of Kashmir (or Kashmiri people). By the late seventeenth century, the term had also evolved into an ethnonym referring broadly to all Muslims but no longer exclusively those Muslims who traced their descent to Kashmir (Powers and Templeman 2012, 570). The dual definition offers a partial explanation of the Indian government's linguistic sleight of hand, allowing it to claim that the Khache were Kashmiri, and thus legally qualified to claim Indian citizenship (Times of India 1959). In 1959, this disagreement over the Khaches' petition resulted in the exchange of dozens of diplomatic notes, letters, and memoranda that ended with China finally yielding and transporting nearly one thousand Khache to the India-Chinese border in late 1960 (Times of India 1960c; Xu 2007, 2:1275).

There is little doubt that the Dalai Lama's departure from Tibet to India had heightened tensions both in Lhasa and between the two emergent Asian powers (Gopal 1976, 89). Indeed many analyses of the period suggest a direct correlation between the Dalai Lama's warm reception in India and a series of border skirmishes that culminated in the 1962 Border War between China and India (Chen Jian 2006; Kennedy 2012). While dozens of popular and scholarly works have parsed the political and diplomatic details surrounding India's harboring of the Dalai Lama and concomitant Sino-India border tensions, the 1960 Tibetan Muslim Incident has been almost entirely overlooked by all but a few scholars of Asia (Abū Bakr and Sharma 2004; Chen Bo 2000; Siddiqui 1991).

Precisely why the two governments seized upon the Tibetan Muslims as a test case in 1959 is not clear. The larger questions of their ethnicity and citizenship are even more startling when one realizes that even as the Dalai Lama crossed over into India—sparking the Indian government's interest in the Tibetan Muslims - the Khaches' precise history, their position in Tibetan society, and their transnational identity remained obscure, ambiguous, and largely undocumented in Chinese, Indian, and Western sources. The extended diplomatic tension between China and India usefully illustrates what Akhil Gupta $(1992,64)$ has noted are the limits of modern concepts of citizenship to characterize those people who occupy "diversely spatialized, partially overlapping or nonoverlapping collectivities." That such concerns lay at the heart of the 1960 Tibetan Muslim Incident starkly demarcates the limits of the non-aligned, anti-imperialist, and pro-Asian solidarity movements of the 1950s, movements that defined both nations' euphoric post-independence/liberation period.

It would be a mistake, however, to perceive the disagreement over the Khache as a deliberate diplomatic maneuver between two Asian powers in which the incident was simply a proxy for broader ideological issues. Specifically, the 1960 Tibetan Muslim Incident, and more specifically the Indian government's calculated rendering of Khache as

entity with varied demographics and historical experiences, I believe the commonalities are substantive enough to bear the weight of the broad label of "Tibetan" and "Tibet"-in the same way we can talk of Chinese, Ottomans, or Russians while still accepting the political, geographic, and ethnic diversity contained within those labels (Shakya 1993, 9; see also Yeh 2007). 
"Kashmiri," echoed a growing consternation across Asia with regard to the legal status of large diasporic communities and to the strong financial and political ties these communities had to their ancestral countries of origin. As Itty Abraham $(2008,51)$ has pointed out, "within Asia, the presence of Indians and Chinese outside their traditional homelands had been a part of the local social and cultural and economic landscape for long enough that their nationality was quite ambiguous." The misgivings over these communities in an era where indigeneity increasingly shaped nationalist sentiments was more than simply a question of sorting out the national origins of specific populations. Just as "Kashmiri" was an imperfect term to refer to the Khache living in Tibet, across Asia questions were being asked about the status of the resident overseas Indian or Chinese populations who had resided outside their country of origin, in many cases for generations (Godley 1989).

The seemingly innocuous labels for such communities hid highly fraught undercurrents and prejudices. The depth of emotion that such terms elicited in the postcolonial era caught many unawares. For as Anna Lowenhaupt Tsing $(2009,40)$ reminds us: "[w]ords in motion surprise us. Their far-flung antics interrupt conventional intellectual history, with its assumption of stable genealogies of thought. They are spread too far for the boundaries of national history; they ricochet too widely to follow strictly colonial geographies. Words in motion urge us to consider multiple linguistic and cultural legacies in dialogue." Similarly, the power of the 1960 Tibetan Muslim Incident to serve as a lens of analysis lies in its ability to capture in unexpected ways the changing relationship of space and identity that accompanied the decolonialization and reterritorialization of Asia. In this light, the Khache controversy was emblematic of hardening conceptualizations of "nation" and "citizen" occurring across postcolonial Asia.

The postcolonial elation that many newly independent Asian nations experienced in the transition from colony to nation-state coexisted with an equally conspicuous anxiety to demonstrate their ability to flourish without Western involvement. Out of this ethos, twenty-nine newly independent Asian and African nations came together in Bandung, Indonesia, to lay the groundwork for a future free from their former colonial rulers, and to explore ways to avoid the emerging divisions imposed by the Cold War. Held in April 1955, the Bandung Conference is largely remembered for the symbolic and ideological international ideals to which the meeting gave voice. One of the most tangible outcomes was the Sino-Indonesian Dual Nationality Treaty, a bilateral treaty between China and Indonesia specifically seeking to resolve the dual-nationality question of Overseas Chinese (Ch. huaqiao 华侨) living in Indonesia (Lee 2010; Tan and Acharaya 2008).

If the Bandung Conference underscores the consternation of a large number of Asian nations over the question of diasporic populations caught out by postcolonial redrawing of political boundaries and the resulting questions over who should and should not be considered a citizen of that newly formed nation, the 1960 Tibetan Muslim Incident, in a similar manner, demonstrates (aside from several notable exceptions), how such incidents have been unremembered (or omitted entirely) from conventional renderings of Asia's past. Nile Green, in his recent examination of Indian Muslims' alternative but unrealized futures with Japan in the interwar period, noted that the term "alter-national" helps "bring to light a range of alternative agendas" and that the study of such events allows us to "decenter the teleology of the Indian nation-state from the alternative but forgotten futures" (Green 2013, 612-13). In both India and China, the 
disagreement over the Khaches' claims to Indian citizenship was prominent in the media of both countries and referenced repeatedly by governmental officials in public and private forums. Yet within months of the incident, the alternative futures sought by the Khache, while positively enabled by economic globalization were, in the end, subverted by the very nature of the national citizenship that permitted their departure from Tibet.

If the alter-national positioning of the Tibetan Muslims helps accentuate their parallel and contemporaneous religious and political positioning that differentiated them from their Tibetan Buddhist neighbors, Carole McGranahan's (2010) conceptualization of "arrested histories" provides a constructive way to delineate how their place in Tibet's history remains intact but inaccessible. The Khaches' historical position in Tibet's past reflects that of Tibet more broadly in that it "is more complicated than a sweeping under the rug of inconvenient past and politics; it is a delay or postponement of histories for the present only" (McGranahan 2010, 25). Not abandoned or erased, the Tibetan Muslims have always remained in plain sight yet never quite in focus. They have been screened off within the official chronicling of the past, since they do not fit comfortably in the current historical narrative of Tibet.

It is in this awkward space-never entirely ignored but never fully integrated-that the Tibetan Muslims have persisted in the historical narrative for over three centuries. Virtually every Western visitor who passed through Tibet-from the earliest Jesuits to Lhasa's most famous foreign resident Heinrich Harrer-referred in some manner to the Khache (Desideri, Sweet, and Zwilling 2010, 665; Harrer 1954, 157; Huc and d'Ardenne de Tizac [1850] 1925, 2:183-84). Chinese sources follow a similar pattern, recording among other details the size and number of mosques in Lhasa from the early seventeenth century onward, describing and even enumerating the Khache communities across Tibet (Fang 1992; Jiao [1721] 1966, 52a-b; Wu and Songyun [1721] 1982, 16). To grasp the nature of the Tibetan Muslim community, one must first address the means by which the Khache so successfully integrated themselves into Tibetan society and how they retained the hybrid influences of Tibet's external neighbors-South Asia, Central Asia, and China - as well as Tibet's elaborate internal intricacies. While the Tibetan Muslim communities across Amdo, Kham, and Ü-Tsang shared many qualities with those described below, this analysis focuses primarily on the experiences and events of the Tibetan Muslims living in Lhasa.

To appreciate the complexities of the 1960 Tibetan Muslim Incident we need, on the one hand, to pay attention to the processes that reterritorialized, relabeled, and renationalized the Tibetan Muslims as "Kashmiri Muslims." On the other hand, we must also examine the manner by which the Tibetan Muslims had, in time, space, and memory, become incontrovertibly Tibetan. The history and memory of the Khaches' past have interacted in unusual ways with mainstream Tibetan, and Asian, historiography, making it a particularly elusive narrative to reconstruct. Precisely because of the lack of documentation, the 1959 dispute between Indian and Chinese officials over the term "Khache" serves both to attest to their arrested history and to suggest that the term itself is a productive starting point in beginning to elucidate their place in Tibet's past. 


\section{THE KHACHE}

It is often assumed that to be Tibetan is to be Buddhist and, axiomatically, to be Muslim precludes one from being Tibetan. Yet, from a Tibetan perspective, particularly in central Tibet, Tibetan Muslims' non-Buddhist religious beliefs did not preclude them from being considered as active and full participants in local Tibetan society (Dorjee and Giles 2005, 140; Ekvall 1960, 377; Ramble 1993, 22; Yeh 2009; see also Dawa Norbu 1992). Nor were Tibetan Muslims a small or insignificant part of Tibetan society. By 1950, more than 10 percent of Lhasa's roughly 30,000 lay inhabitants were Muslim (Goldstein 2007, 244; Kaul 1976, 103). ${ }^{2}$ Lhasa alone had four mosques and two Muslim cemeteries, and by the early twentieth century mosques were present in virtually every large central Tibetan city, including Shigatse, Gyantse, and Tsetang (Gaborieau and Muham$\operatorname{mad} 1973,20)$.

Still, the notion of Tibet as a monolithic and homogeneous Buddhist society lingers despite the numerous studies that have highlighted Tibet's diverse Mongolian, Bon, Newari, and Sherpa communities (Cabezón 2010; Gellner 1992; Ortner 1989). Geoffrey Samuel's landmark study of Tibetan culture, society, and religion, Civilized Shamans, is at its core a multi-themed soliloquy positing a single point: that "premodern Tibet contained a greater variety of social and political formations than is often appreciated" (Samuel 1993, 39). Reflecting this ethnic and regional diversity, the Tibetan Muslim communities exist in virtually all areas of Tibet: as far west as Baltistan, Kashmir, and Ladakh; as far east as Dartsedo (Ch. Kangding 康定) in eastern Kham; as far north as Labrang Monastery in Amdo; and as far south as the Himalayan hill towns of Kalimpong and Darjeeling in northern India. Yet with several notable exceptions, there has been little sustained scholarly inquiry into the presence of Tibetan Muslims in mainstream Tibetan society (Abū Bakr and Sharma 2004; Akasoy, Burnett, and Yoeli-Tlalim 2010; Fischer 2008; Gaborieau and Muhammad 1973; Horlemann 2012).

A central obstacle to understanding Islam's stature in Tibet has been the lack of clarity made in previous studies between Tibetan Muslim permanent residents and Muslim sojourner communities within Tibet. Islamic historians and geographers recorded numerous Muslim travelers, caravaneers or merchants, and even a mosque, as early as the eighth century (Beckwith 1989, 164; Khatchikian 1996, 132; Minorsky, Bartol'd, and Bosworth 1970, 92-93). While there is virtually no documentary evidence-in Tibetan, Chinese, or any other language-that can offer insight into the specific nature of the Muslim communities in this early period, the details that do survive suggest that, until

\footnotetext{
${ }^{2}$ Precise estimates of the Muslim population are difficult to come by and often confused by the ambiguity of the term "Hui" (Muslim Chinese), which is often selectively applied both in the Republican and PRC periods to refer to all Muslims, including recent immigrants from the Chinese interior and other areas. In 1959 and 1960, the years for which the most precise estimates are available, Lhasa was, conservatively, home to 3,000 permanent Muslim residents (see FBIS 1959a; Times of India 1960d). While one Tibetan Muslim estimated that there were over 1,000 Muslim households in Lhasa in 1946 and several Western sources cite Broomhall's inflated estimate of 2,000 families (Arnold 1913, 296; Broomhall 1910, 206; Yiwu 1946), more cautious estimates suggested over 350 families in Lhasa, 150 in Shigatse, and another 20 in Tsetang (see Gaborieau and Muhammad 1973, 30; Peter 1951, 234).
} 
the late sixteenth century, Muslims tended to be long-term visitors but few made Tibet their permanent home.

Part of the evidence for this can be inferred from the fact that Muslims in Tibetan documents were typically designated by a variety of more or less pejorative terms, such as lalo (barbarian), mutekpa (infidels), or gokar (white hats), which emphasized their externality (Desideri et al. 2010, 265, 665; Henry et al. 1997, 19; Rajesh 2005, 207; $\mathrm{Wu}$ and Songyun [1721] 1982, 10, 32). ${ }^{3}$ By the fifteenth century, the Nepalese chronicle Vamshavalis noted that the first Kashmiri settlers in the Kathmandu valley were Muslim Kashmiris traveling between Kashmir and Lhasa (Dastider 2007, 90). The Kashmiri, as the earliest Muslim sojourners in Lhasa, likely caused the Tibetan term for Kashmiri, "Khache," to quickly be conflated to mean any Tibetanized Muslim who resided within Tibet and semantically widened to include other Muslims who traced their origins to China and Central Asia (Ma Jianye 1947, 12). ${ }^{4}$

The confusion over the Khache typically falls into one of the following two categories. First, outsiders-Westerners and Chinese alike-tended to gloss "Khache" using terms that connote external non-native terminologies, creating an impression that no "indigenous" Muslims (e.g., Tibetan Muslims) existed. Matters were further confused when foreign observers proceeded to use all of these terms more or less interchangeably, sometimes calling the entire community "Ladakhi," at other times "Kashmiri," and in Chinese glossing any Muslim in Tibet as "Hui"-a blunder that few Tibetans would make (Chapman 1938, 96; Ma Jianye 1947; MacDonald 1932, 247; Sandberg 1906, 174; Waddle 1905, 346; Wu and Songyun [1721] 1982, 329). Representative of just such a predisposition, the Indian government in the first months of its official correspondence with the Chinese referred to "Ladakhi and Kashmiri Moslems" (IMEA 1960 I, 85), then just simply "Kashmiri Moslems" (IMEA 1960 II, 72), and later on as "Kajis" (IMEA 1960 III, 123).

Second, attempting to gloss the Khache unequivocally as Tibetan Muslim is hindered by the fact that in the pre-twentieth-century era there exists no single Tibetan word that is equivalent to the modern word "Tibetan" (Tib. böpa). To confuse the picture even

\footnotetext{
${ }^{3}$ As John Newman's research on the Kālacakra tantra has shown, references to Islam and Muslims appear as early as the eleventh century and outnumber all mentions of pre-Buddhist religions combined. While Islam is described as "a perfect anti-religion which is the antithesis of Buddhism," Newman $(1998,331)$ concludes, there is no systematic attempt to demonize Muslims, to the contrary, characterizing them as "truthful, clean, honest and chaste." Some have suggested that gokar [mgo dkar] is derived from either the Chinese chantou Hui 缠头回 (turbaned Hui) or the Mongolian cayan malayai. Trent Pomplun (2010, 264-65n107) notes in his study of Jesuits in Tibet that the term was also applied to European missionaries and speculates that it seemed to have "many of the same connotations as the mildly pejorative faringi" (see also Li 2006, 44; Pelliot 1947, 130-32; Pollock 2011, 345; Rockhill 1891, 111n2).

${ }^{4}$ There is some debate over the actual roots of the term khache. Most simply suggest the term is derived from the Tibetan word for Kashmiri (khaché) or Kashmir (khachul), which existed long before the arrival of the Tibetan Muslims (e.g., a chief export of Kashmir was saffron, referring to it as "Kashmiri saffron" [khaché 'kyé] (Das [1902] 1970, 126; Radhu 1997, 161). Some scholars suggest that the term is derived from the Ladakhi term for Kashmiri Muslims, khachur, sometimes Romanized as khachad (Abū Bakr and Sharma 2004, 51; Siddiqui 1991, 76). Marc Gaborieau posits that the term is derived from Persian khwâja (Gaborieau 1995, 21). For an excellent overview of Ladkahi Muslims, see Bray (2012).
} 
further, a considerable amount of slippage existed between the religious and ethnic registers. In this way, in Tibetan, "Khache" could, and sometimes did, simply mean someone who practiced Islam. In other contexts, "Khache" acquired a more ethnic (or ethnoreligious) connotation to designate those Muslims who had lived in central Tibet for generations, were native speakers of Tibetan, and in many cases had intermarried with local Tibetans.

Finally, as the very premise for the 1960 Tibetan Muslim Incident exhibits, there remained a presumption among many non-Tibetans that, even in the mid-twentieth century, Khache were some sort of perpetual non-native. To properly frame the 1960 dispute between China and India over the Khache, we must recognize that the Tibetan Muslims under examination here are in no way part of the sojourner Muslim communities. There is no dispute over the fact that, for centuries, large numbers of Muslim traders from Central Asia, India, and China perennially guided caravans to the major markets of Tibet and often wintered in Tibetan urban centers before making their return journey. These sojourner Muslims, however defined, did not at any time prior to 1960 form a majority of the Muslims in Tibet. ${ }^{5}$ More significantly, with regard to the 1960 Incident, all parties-Tibetan, Chinese, and Indian-agreed that central Tibet's Khache community was not a sojourner community. From the very beginning, then, the issue was not over the question of whether the Khache were sojourners. Rather, the question being contested was at which point does any community, under international law, lose the right to revert back and claim the citizenship of their ancestors' country of origin. A key aspect of this question is to discover when and how Tibetan Muslims first established themselves as a permanent community in central Tibet.

Almost all political records, external accounts, and oral histories suggest that the earliest permanent Tibetan Muslim community emerged in the seventeenth century under the reign of the Fifth Dalai Lama (1617-82). Given the Fifth Dalai Lama's leading role in establishing the Ganden Podrang, the political administration of central Tibet, it is not surprising that his reign marks the first period in which sustained evidence of Tibetan Muslims emerged. Noted Tibetan scholar José Cabezón suggests a strong linkage between the emergence of a permanent Muslim community and the Fifth Dalai

\footnotetext{
${ }^{5}$ The sharp increase in Muslim Chinese Hui residing, either permanently or temporarily, in Lhasa only began in the 1980s. Their presence has considerably altered the connotation or subtle nuance of what it meant to be Khache. With the rise of Chinese as the common language in Tibet and the imposition of the minzu categorization upon that populace, the complex and often fraught ethnoreligious differences between being Hui and being Khache have become increasingly tangled. In the 1950s, the majority of Khache referred to themselves as Hui when speaking Chinese, but not all identified themselves as Hui on their household registration (hukou) and later identity card (shenfenzhen). This is not to say the Chinese language was entirely deficient in this regard since, for many centuries, Chinese speakers (orally and in writing) referred to the Khache using an array of Chinese homophones, such as 卡契 (kaqi), 卡切 (kaqie), 卡基 (kaji), 卡基 (keji), 客迦 $(k e j i)$, 喀迦 (kajia), etc., to refer to the Tibetan Muslims in order to differentiate between them and the Hui (those Muslim Chinese from northwest China who had not acculturated to Tibetan society). Conversely, Tibetan also reflected the evolution from Hui-hui (Tib. hühui) to Hui (Tib. hürik), to Huizu (Tib. haérik), as well as the lingering mingling of all three terms and variation among different regions. For a range of these ethnonyms, see especially the range of terms spread from the imperial to the modern period (Meng [1852] 1978, 1:13a-16b; Wenqing, Zhen, and Baoyun [1930] 1963, 5:13b-16b; Xu 2007, 1282).
} 
Lama’s "invitation of the [non-Tibetan] peoples" (Tib. mina drönpo) as "part of a larger policy of encouraging ethnic, cultural and economic diversity in Tibet" (Cabezón 1998, 19). Almost certainly the vibrancy and political stability of the Fifth Dalai Lama's reign enabled the Tibetan Muslims to habituate themselves to Tibet and Tibetan culture in ways that transformed them from a simple immigrant community to one deeply integrated within Tibetan society (Boulnois 1983, 154).

Tibetan Muslims quickly became active in all segments of Tibetan society. Their literacy and fluency in Tibetan, particularly the facility with which they eloquently deployed the elaborate honorific register (Tib. zhesa), quickly marked them as among the most literate and eloquent lay speakers and writers of Tibetan. Tibetan Muslims also excelled in the Tibetan nangma musical tradition popular among both its rural nomads and Tibet's urban elite (Chapman 1938, 110-11; Samuel 1976, 408). Nor were the Tibetan Muslims excluded from public service. In the historical record, Tibetan Muslims often served in official roles in the Tibetan government and even in the service of the Dalai Lamas themselves (IOR L/PS/12/4202 5318, September 16, 1945; Ma Jianye 1947). Over the course of three centuries, the Tibetan Muslim community in Lhasa and central Tibet had come to form such a constitutive dimension of Tibetan society that, up until 1959, their presence and role was rarely remarked upon as a source of concern or a focus of violence.

Within Lhasa, the Khache community was divided along linguistic and cultural lines between those of South Asian and those of Chinese heritage (Ma Jianye 1947, 12; Wenqing et al. [1930] 1963, 5:13b-16b; Yiwu 1946). In turn, each group became known by the neighborhood—-the Barkor (Tib. barkör, Ch. bakuo 八廓) or the Wabaling (Tib. wabaling, Ch. Hebalin 河坝林) - in which they settled and built their mosques (Altner 2010, 348-49; Gaborieau and Muhammad 1973, 25-27; Peter 1951, 237; Tshe rdor 1992; Yang [1814] 1967, 194:33b). The Barkor (South Asian) Khache, predominantly involved in commerce, clustered around the central Barkor market area near the Jokang Temple. The Wabaling (Chinese) Khache lived along Lhasa's Wabaling neighborhood in the southeastern corner of Lhasa near to the Lhasa River, closer to their fields and the areas in which they were allowed to butcher animals (Ciduo 1992, 115; Meng [1852] 1978, 1:13a-16b).

In the eyes of the Tibetans and the Tibetan government, the two groups remained legally, culturally, and socially distinct from each other. Each group had an appointed leader (Tib. pönpo or gopa) and their Muslim council (Tib. khache gopa). ${ }^{6}$ The Tibetan government's central council, the Kashag, by the late nineteenth century had designated different bureaus within the government to oversee the Barkor and Wabaling Tibetan Muslims. In the case of the Barkor Tibetan Muslims, their self-selected leader (Tib. khache pönpo) reported to the Finance Ministry, since they were predominantly engaged in trade and commerce. The Wabaling Tibetan Muslims selected a separate leader (Tib. Wabaling pönpo) who reported directly to the Agriculture Ministry. In both cases, the immediate goal of such governance was to establish positions of leadership for each community, through which the government could tax, administer, and oversee

\footnotetext{
${ }^{6}$ Also often referred to in English-language sources as Khache ponj or "punch," deriving from a Hindi term for five and the fact that the committee by the early twentieth century had five members.
} 
them. However, it was also an acknowledgment that as non-Buddhists they were explicitly exempt from statutes and conventions that were guided by Buddhist principles (French 2002, 167-68, 278; Gaborieau and Muhammad 1973, 26-27; Ma Jianye 1947; Siddiqui 1991). It should be noted that these two communities were, in turn, distinguished from the other Nepalese, Ladakhi, and other foreign communities who had formal standing in the eyes of the Kashag.

By the twentieth century, both the Barkor and Wabaling Khache were highly Tibetanized and displayed strong religious, marital, and commercial relationships both inside and outside the broader Muslim community (and between the two Muslim communities). Over the course of the twentieth century, the Khache community continued to play a central role in Lhasa. One prominent Muslim Chinese Hui intellectual, upon arriving in Lhasa in the early 1950s, remarked that the Wabaling Khache were outwardly largely indistinguishable from the Tibetans, and also remarked how different they were from Chinese Hui (Ch. neidi Huizu 内地回族) (Xue 1986, 72-75). The abrupt arrival of the People's Liberation Army in Lhasa however would push them into a position of unaccustomed prominence.

\section{Tibetan Muslims: Bystanders, Victims, or Handmaidens of the State?}

In late 1951, over eight thousand Chinese soldiers arrived in Lhasa, marking a new era for the capital. Lhasa during this time, like many cities in the early phases of occupation by a new political force, was a city of contradictions, political machinations, and cultural clashes. Following Mao Zedong's explicit instructions, the newly established Chinese government adopted a gradualist approach. As Melvyn Goldstein $(2007,543)$ describes it, the Chinese officials in Lhasa "set out to develop cooperative and cordial relationships with the elite and to convince them that these officials had come to Tibet to help them modernize and develop, not to oppress and exploit them, as previous Chinese regimes had done."

Lhasa's social calendar — with its Tibetan Buddhist rituals, daily prayers, and constant flow of pilgrims - proceeded largely unabated. Tibet remained one of the only places in China where Chinese silver dollars from the Republican era and not the newly introduced “People’s money" (Ch. renminbi 人民币) served as the legal tender. The Kashag, the Tibetan governing council, and Tibetan monasteries persevered institutionally but functioned with decreasing autonomy. The Dalai Lama continued to play a central role in the institutional and cultural life of the city while serving as the primary mediator between the realities of Chinese control and the limitations of Tibetan authority.

For the Tibetan Muslims, the 1950s marked an era of opportunity and unaccustomed scrutiny by both Tibetans and Chinese. From all accounts, Lhasa's Tibetan Muslims fared better than the average resident. In Lhasa, the sudden influx of Chinese soldiers and officials had precipitated food shortages and a sharp rise in the prices of basic foodstuffs. The arrival of Chinese soldiers and officials provided an unexpected commercial windfall for all of Tibet's traders generally but also for the Tibetan Muslims in particular. As a result of the Seventeen-Point Agreement signed in 1951, traders could still import foreign goods from India that were severely proscribed in China proper. Demand swiftly outstripped supply. Immediately realizing the 
remunerative potential, the Barkor Tibetan Muslim traders quickly abandoned the importation of textiles, cigarettes, and kerosene, and branched out into high-value, low-bulk luxury items such as European pens, watches, and even batteries (Harris 2013, 12, 39-40). Xinhua News Agency photographer Chen Zonglie recalled his shock, soon after of his arrival in 1956, at being escorted to the Barkor and seeing the stalls "fully stocked with goods that one almost never saw in interior China such as brand-name Swiss watches, French perfume, Italian accordions, German cameras, American Kodak film, ... Indian silk, spices, condensed milk and desserts, as well as Nepalese Buddhist figurines and ceremonial instruments, etc." (Chen Zonglie 2009, 20). The demand was such that Tibetan Muslim caravaneers boasted of selling off their complete inventory within days of arriving in Lhasa.

As a result, while the Barkor Khache found the political situation far from ideal, economically life in the 1950s was even more prosperous than in the 1930s and 1940s. In 1957, forty-one Barkor Tibetan Muslims could afford the high costs associated with going on pilgrimage to Mecca-more than double the number who went ten years earlier and twice the number that travelled from the interior provinces with the official hajj delegation (Xizang ribao [1957] 1968; Yiwu 1946, 12; Zhongguo Yisilanjiao xiehui 2011, 855). Many more Khache families could bear the expense of sending their children to study in the Indian hill stations of Kalimpong and Darjeeling or even Delhi. A Barkor Khache family even succeeded, in 1958, in receiving the permits necessary to open the Happy Light Movie Theater, where, in addition to Chinese films, they managed to screen the occasional Hindi film right up until 1959 (Rahul 1961, 181). For the Barkor Khache, in spite of the politically restrictive nature of Chinese rule, the economic freedoms and opportunities meant that "a certain euphoria spread through quite a few circles in Lhasa" (Radhu 1997, 248-50).

If the Barkor Khache were prospering economically, the Wabaling Khache profited as linguistic, cultural, and political brokers between the Chinese and Tibetans. With the dearth of Tibetan-Chinese translators, Wabaling Khache emerged as critical interlocutors for Chinese officials and soldiers (Tsarong and Chödron 2000, 199). The perceived pro-Chinese stance of the Wabaling Khaches gradually came to vex many local Tibetans (Suo 2002, 60). Former Tibetan government official Tubten Khétsun, with a bitterness undiminished decades later, recalled that the Wabaling Khache "welcomed and cooperated with [the Chinese Communists] like a baby embracing its mother" (Khétsun and Akester 2008, 150).

By 1958, this outward facade of normality began to crack. Increasing numbers of Kham Tibetans from eastern Tibet began appearing in Lhasa, fleeing the increasingly harsh political reforms occurring outside of the administrative borders of the Tibet Autonomous Region. As the broader situation became clear, many in Lhasa, including the Dalai Lama, reevaluated Tibet's relationship with China's central government (Goldstein, Sherap, and Siebenschuh 2004, 74, 208; IMEA 1959 II, 74). Speculation surrounding impending Chinese troop reinforcements and the increased swirl of rumors suggesting Chinese plans to seize the Dalai Lama exacerbated the already unsettled mood in Lhasa. When on March 17, 1959, the Dalai Lama and his closest advisors fled Lhasa for the two-week trek to India, the period of the Tibetan Muslims both benefiting from the Chinese presence yet remaining politically ambivalent had come to an end. 
As the news of the Dalai Lama’s departure became known, violence swept across the Tibetan capital (Goldstein 2013, 9; Khétsun and Akester 2008, 22-23). Both Tibetans and Chinese-already tense, angry, and suspicious of one another-began a fierce fight for control of the city (McGranahan 2010, 105). According to Xinhua News Agency, the following day, on March 19, at 10:00 a.m., the Chinese People's Liberation Army was "ordered to take punitive action against the clique of traitors who had committed monstrous crimes" (Renmin ribao 1959d; for an English translation see also Xinhua News Agency 1968, 351). Particularly bloody clashes occurred around the Norbulingka Summer Palace and the Potala Palace as the Tibetan centers of resistance struggled to repel the Chinese military assault.

Rarely remarked upon in most accounts of the uprising is that on March 19, along with several infamous attacks against pro-Chinese Lhasa secular officials, the Wabaling Khache community also became a primary target of Tibetan "anti-collaborationist" violence (Shakya 1999, 192-93). By the end of the day, the centuries-old Grand Mosque and several dozen Wabaling Khache residences were burned to the ground. Khache homes and shops along the market were looted and ransacked. Yet not a single Chinese soldier was dispatched to protect the Wabaling Khache or their property. Fearing for their lives, many Wabaling Khache instead sought out the soldiers, taking shelter in the People's Liberation Army's encampment outside of the city (FBIS 1959c; Renmin ribao 1959e, 2; Zhang 2002, 28). The attacks on the Wabaling Muslims were not simply a case of a minority population being caught in the crossfire of a violent insurgency. Rather, the Wabaling Khache had, in the eyes of many Tibetans, become clearly identified as colluding with the Chinese and thus became early targets of their violence.

For the Beijing central government, the Tibetan attacks on the Wabaling quickly became a cause célèbre. Between the end of March and early May, the People’s Daily featured the Wabaling prominently in a half dozen front-page articles detailing the Lhasa Uprising. The earliest articles characterized them as local supporters of China's military response to the March Uprising. Under the front-page headline "The People of Tibet Enthusiastically Uphold Suppression of Rebels," two senior Wabaling imams decried "the rebels' monstrous crimes of looting and burning Lhasa," and noted that the Tibetan rebels' "crimes reached up to the heavens bringing calamity to both the country and the people" (Renmin ribao 1959a).

In the following weeks, two more People's Daily articles highlighted the Wabaling as part of an effort to highlight the trauma the uprising had inflicted upon "normal Tibetans" and to undermine the notion that the rebels were seeking to "protect religion." These last two articles were particularly powerful, since they featured photographs of Muslims holding their Friday prayers in the burned-out shell of the Grand Mosque and a Wabaling Khache standing in the remnants of his burned-down home (Renmin ribao 1959b, 1959c). Deployed in this manner, the Wabaling Khache emerged as powerful instruments of the Chinese central government's claim that the Tibetan rebels were a minority intent on reversing the positive achievements of the People's Republic since its arrival in Lhasa.

Notably, the People's Daily articles almost always referred to the Wabaling Khache generically as Hui (Muslim Chinese). No mention or distinction was ever made of the diversity within the Lhasa Muslim community (or noting how these Hui were not 
"Chinese Muslims" of interior or even northwestern China). ${ }^{7}$ Never, for example, did the media reports divulge that Tibetans neither desecrated the Small Mosque nor destroyed a single Barkor Khache home. Not surprisingly, government coverage avoided mentioning why the Wabaling Khaches had been targeted. There is little doubt that the Tibetan rancor stemmed from the fact that Wabaling Khache had accompanied Chinese soldiers and officials serving as translators, actively helping the Chinese and "behav[ing] with unlimited arrogance" (Khétsun and Akester 2008, 150). Clearly, the Tibetans' attacks were founded far more on the Wabaling Khaches' pro-Chinese stance than, as the People's Daily had its readers believe, the rebels' anti-Muslim beliefs.

There is no doubt that the Chinese government's ambiguity on the matter emerged out of expediency, not ignorance. As quickly as the government acted to promote the victimization of the Wabaling Khache, it moved to suppress what it considered to be the Barkor Khaches' threat to the city's tenuous calm. On March 21, within days of the Dalai Lama's departure, the Chinese detained and arrested Hamidulla (Rapse) Masle, the senior leader (Tib. Khache pönpo) of the traditional Khache council, and by the end of the year had imprisoned all five members of the council (IMEA 1963 X, 88). Within the week, the Chinese officials informed the Barkor Khache that all "previous laws and documents [regarding their Indian citizenship] were to be deemed as cancelled and no claim was to be accepted unless it was backed by fresh documentary proof" (TMRA 1959, Letter \#1 to Kalimpong, 3). Chinese officials went to the Barkor Khache residences and businesses demanding that they declare themselves Chinese. Those who refused were taken for extended interrogation sessions that resulted in several Barkor Khache being forcibly coerced into declaring themselves Chinese citizens.

Even with these arrests immediately after the March Uprising, it was not until early April, as Ramadan came to an end, that the Barkor Khache leaders "approached the Indian Consulate for aid whereby they hoped to bring about the migration of the whole community to India" (Naik 1995, 33). The Chinese government responded by posting guards outside of the consulate to prevent the Khache from meeting with the consul-general and, according to some sources, fired warning shots to prevent them from even approaching the Indian consulate (IMEA 1959 I, 85). India's interest in the Khache deeply disconcerted China. Originally India was seen as an Asian ally that had also thrown off the yoke of an imperialist past, but by the late 1950s China became increasingly nervous regarding the only Asian nation capable of challenging its authority.

Significantly, the first time that either China or India addressed the question of the Tibetan Muslims' nationality occurred on April 27, 1958. On this day, nearly a year before the Dalai Lama left Tibet, the Indian consul-general in Lhasa and his Chinese counterpart, the Chinese Director of the Foreign Bureau in Tibet, discussed the issue. The matter seems to have been dropped almost as quickly as it was raised, that is, until

${ }^{7}$ While Chinese newspapers consistently referred to all Khache as "Hui," most of the community had registered as Tibetan in their household registration (hukou) and later, when introduced, in the identity cards (shenfenzhen). In Lhasa, Hui (Tib. hürik) was reserved for Muslim Chinese. The implications of this are significant given that a Tibetan Muslim registering as Hui was far more common in the eastern Tibetan areas of Kham and Amdo, which fell outside of the territory that would eventually form the Tibetan Autonomous Region. I can find no record of any usage of the term "Zang-Hui" for the Lhasa community prior to the 1980s. 
Consul-General S. L. Chhibber revived the issue over a year later in May 1959. In a note to the Chinese Director, he asserted that his own investigation into the matter had led him to the conclusion that "the Kashmiri Muslims and other Indians living in Lhasa and Shigatse should be treated as Indian nationals" (IMEA 1959 I, 84-85). The Chinese Director's reply on the matter was equally concise and unequivocal: "These assertions are opposed to the historical facts and I cannot agree with them” (IMEA 1959 I, 86). Not deterred by China's position, Chhibber met with the Barkor Khache and distributed forms for them to register as Indian citizens.

From the spring to late summer of 1959, the parameters of the dispute over the Barkor Khache remained for all parties involved-Indian, Chinese, and the Khachelargely a reiteration of previous assertions about historical precedents. Three factors remained fixed at the center of such assertions: (1) the status of the Khache under the Tibetan government prior to 1950; (2) the issuing agency of the Khaches' passport or visa to travel to Mecca on the Haj; and often (3) the assertion that the term "Khache" meant Kashmiri and thus, ipso facto, the Khache should be adjudged to be Indian citizens (IMEA 1959 I, 84-85, 89-90; Times of India 1960b; TMRA, August 1959). In late August, however, two seemingly unconnected events-a border skirmish in the Sino-Indian border outpost of Longju and an anti-Chinese trade ban in Indonesia preceding the ratification of the Dual Nationality Treaty-dramatically altered the context and rationale with which both China and India would interpret and portray the Lhasa Khache.

\section{BANDUNG}

Sino-Indian actions during the 1950s tend to be characterized as a result of either security concerns or a clash of worldviews (Dawa 1997; Liu 1994; Ma Rongjiu 2014). Certainly, on the surface, it is tempting to see China and India as two regional powers battling for ideological and territorial supremacy: the former evidenced in the Dalai Lama's harrowing escape from communist China to a democratic India and the latter seen as escalating clashes over a geopolitically significant boundary. Yet such explanations tend to be overly deterministic as a result of a narrow, selective, and even teleological ordering of events.

As noted in the introduction, post-independence unease arose across Asia in part because of a realization that the notions of indigeneity and citizenship were unstable, often situational, categories upon which to base citizenship. Along with a postcolonial euphoria, most every nation in Asia grappled with a post-independence crisis of identity. China and India recognized quite early that their own political security relied upon a stable Asia, and conversely, that a stable Asia required that they appear to be working towards resolving the question of their respective overseas communities of Indians and Chinese.

The paradox of the 1960 Tibetan Muslim Incident is that the confrontation between India and China occurred after a decade of careful Sino-Indian diplomacy, a diplomacy emerging out of each nation's shared struggle for independence and liberation from an anti-imperialist past. In the early 1950s, neither India nor China perceived their pursuit of international stature as a zero-sum game. Nehru had advocated on China's 
behalf numerous times, not the least his consistent backing of the People's Republic of China's membership to the United Nations. Nor did China's invasion of Tibet alter his stance. Staunchly pro-Tibet, Nehru hewed to a distinctly pragmatic line, noting in an internal memo: "There is no likelihood whatever of Tibet being able to resist [China's occupation] or stop it. It is equally unlikely that any foreign power can prevent it. We cannot do so" (Nehru 1984, 343).

Often characterized by his detractors as pursuing a policy of appeasement towards China, Nehru's stance was far more nuanced. In the same internal note, he displays his characteristic intellectual acuity by clarifying that his lack of action is based on his belief "that neither the U.K. nor the U.S.A., nor indeed any other Power, is particularly interested in Tibet or the future of that country. What they are interested in is embarrassing China. Our interest, on the other hand, is Tibet, and if we cannot serve that interest, we fail" (Nehru 1984, 346; see also Anand 2009, 245-46). Nehru's engagement with China was based on the early realization that Asia's largest problems could only be approached collaboratively. For this and other reasons, Nehru actively championed China's participation in the Bandung Conference in 1955.

A central motivation for Nehru's desire to have China attend the Bandung Conference lay in his desire to find a diplomatic solution for the Indian and Chinese communities living outside of India and China. The dilemma for both India and China was that these external communities were perceived as retaining enduring yet ambiguous ties to their homeland and thus were seen as "a source of internal conflict and threat" by the host communities (Abraham 2008, 57). While all parties agreed that the implicit dualnationality of these communities posed a problem, the obvious solutions required multilateral agreements across Asia. Extremely sensitive to the accusation of fostering neo-colonialism, China and India sought to acknowledge their lingering ethno-cultural ties to these communities while advocating that they accept citizenship in the country of residence.

A tentative postcolonial expression of Afro-Asian unity, the Bandung Conference sought to forge a Third World alliance independent of the First World powers and the creation of a neutral space between communist and noncommunist nations. Indonesian President Sukarno captured the boundless optimism of the conference in his opening speech when he set out the task of the twenty-nine African and Asian participant nations as nothing less than to "demonstrate to the minority of the world which lives on the other continents that we, the majority, are for peace, not for war" (Kahin 1956, 50). With a deep desire to offer tangible evidence of a triumph fostered by the "Bandung spirit," China and Indonesia emerged at the end of the meeting with a bilateral accord on dual-citizenship. The agreement clarified the process by which the citizenship status of "overseas Chinese" (generally defined as persons of Chinese descent) who had, at the end of Dutch rule in 1946, passively acquired Indonesian nationality-though still being considered ethnically alien-could be resolved. In the context of the Bandung Conference, this protocol captured the conference's resolve to address the undesirable and lingering vestige of colonialism in a peaceful and collective manner. It also appeared to herald a broader resolution of the persistent concerns held by many Southeast Asian nations over the ambiguous status of Indian and Chinese communities outside of India and China. 
If the dual-nationality agreement alleviated the pressure the conference's hosts felt to produce genuine and measurable results, the ratification process revealed the difficulty of transforming lofty sentiments into meaningful action. As negotiations for the treaty's ratification stretched into their fourth year, in the summer of 1959 a complex combination of religious, ethnic, and political tensions culminated in an Indonesian ban on all alien-owned (overwhelmingly Chinese) rural retail stores in Indonesia (Mozingo 2007, 168-75). The Chinese government responded by dispatching embassy employees posted in Jakarta to impede the ban's implementation and, back in Beijing, by subjecting the visiting Indonesian Foreign Minister to middle-of-the-night harangues. Sensing little cooperation by the Indonesian government, China hastily escalated the pressure by dispatching merchant flotillas to repatriate overseas Chinese. Before a mutually amenable treaty was formally ratified in early 1960, over 100,000 Chinese accepted the offer to leave Indonesia and return to China (Godley 1989, 335; Mackie 1976, 92). Yet China's broad, assertive actions on behalf of the overseas Chinese in Indonesia, now headline news around the world, began to interact in perplexing and unexpected ways with the situation in Tibet.

Even before China had played out its strategy in Indonesia, India had, by late September 1959, realized that China's handling of its overseas population in Indonesia had created an opening for it with regard to the standoff over the Khache in Tibet (FBIS 1959b). While domestically China had, over the preceding decade, deftly managed to translate its internal ethnic differences into state-approved nationalities (Ch. minzu 民族) within an overarching framework of Chinese citizenship, it had embraced a definition of "overseas Chinese" that retained clear, but awkward, vestiges of pre-People's Republic of China, Han-centric concepts of what it meant to be Chinese (Vasantkumar 2012, 441).

As China had openly and aggressively demonstrated in its standoff with Indonesia, no amount of time, distance, or even intermarriage with non-Chinese diminished China's ability to declare overseas Chinese as citizens of the People's Republic of China. Hastily seizing upon China's primordialist definition of overseas Chinese-ness, the Indian government turned China's "once-a-Chinese-always-a-Chinese" ethnic logic back against the Chinese, and now asserted that the Chinese, having admitted that the Khache were once Indian, must allow them the opportunity to declare themselves to be Indian citizens.

On September 24, 1959, India delivered a 2,500-word note to the Chinese Embassy in New Delhi that repositioned the Tibetan Muslim Incident not as a historical question of the Khaches' earlier acceptance of Tibetan (and thus Chinese) oversight, but as two liberated Asian partners equally applying a single policy:

As is well known, a large number of persons of Chinese origin have been resident for decades, if not generations in the various countries of South-East Asia without having actually accepted the nationality of the countries in which they reside. In the Agreement which has been concluded by the People’s Republic of China with the Republic of Indonesia, to take only one example, persons of Chinese origin have been given the option to choose between Chinese nationality or the nationality of Indonesia. The Government of India seeks no greater concession in respect of persons of Indian origin in the Tibet region of China than the application to them of a principle which the People's 
Republic of China have accepted in respect of persons of Chinese origin resident outside China. (IMEA 1959 II, 90-91)

Realizing that China's primary evidence had, up until this point, been its historical claim for control over Tibet, the Indian government neatly exposed the intellectual lacuna between China's territorial and extraterritorial logic of Chinese-ness in Indonesia and that of the Khache in Tibet.

The note also explicitly pointed out that the Chinese government's earlier claim that "the Kashmiri Muslims were subject to the jurisdiction of the Tibetan courts, that the selection of their leader was confirmed by the Dalai Lama, that they recognized the Fifth Dalai Lama, and further that they sometimes fought alongside Tibetan forces" was not by itself enough to "constitute conclusive evidence regarding their Chinese/Tibetan nationality" (IMEA 1959 II, 89). In this elegant maneuver, India forced China to either concede in the case with the Khache that, as with the overseas Chinese in Indonesia, ethnic heritage trumped sovereignty or reverse itself and surrender the ideological high ground to India by insisting national boundaries alone defined Chinese citizenship.

China initially refused to concede either point and instead adopted a two-pronged response to counteract India's change of tactics. Internationally, China denied that any double standard existed, insisting that "the Chinese Government cannot agree to the fact that the Government of India should lodge a so-called 'strong protest' against this matter which is purely within the scope of China's internal affairs" (IMEA 1959 III, 123). The Chinese note went on to insist that although international law was clearly on its side, "it is a fact known to all, that foreign nationals in the Tibetan region or any other part of China who desire to return to their country are always given permission" when they apply to the relevant departments (IMEA 1959 III, 124). Treating this statement seemingly as the final word, the Chinese, despite repeated and insistent requests from India, refused all attempts by India to draw the Chinese into discussing the issue further.

Internally, however, the Chinese adopted a rather more strident course of action. Even before the December 31, 1959, response was delivered to the Indian government, local officials in Lhasa, with startling urgency and vigor, began a campaign of intimidation to impose Chinese citizenship upon the Khache by force. Beginning in late 1959, members of the Barkor Khache were repeatedly summoned for interrogations by local Lhasa authorities, their property and cash were confiscated, and they were refused ration coupons, all on the grounds that "they have refused to register themselves as Chinese" (IMEA 1960 IV, 63). While several Barkor Khache broke under the pressure and gave in, the community as a whole continued to resist.

In June 1960, local officials, likely under coercion themselves to bring the impasse to a conclusion, for the first time publically accused the five imprisoned Khache with criminal acts.

With virtually no notice, on the morning of June 20 , the local officials notified all local Lhasa residents, including the Barkor Khache, of a mandatory rally at the newly constructed Athletic Stadium. Upon arrival, as all participants were being divided up into their administrative neighborhood groupings, the Barkor Khache were hastily instructed to leave the stadium and return to their homes. Later they learned that once they had left the stadium, the five Barkor Khache prisoners were paraded before the crowd in the 
manner of a show trial. Four of the five were charged with "incitement of the [Khache] to claim a foreign nationality," with the fifth Khache prisoner additionally charged with writing and displaying a poster promoting the Khaches' pro-India slogan. All five received prison terms of eleven to fifteen years (IMEA 1960 IV, 63). The message to the other Khache was unmistakably clear: drop their claims for Indian citizenship or be accused of political crimes.

The campaign of terror increased as the Chinese broadened their efforts to menace, bully, and harass key members of the community with beatings and threats that they "would be shot dead" (IMEA 1960 IV, 67). Having already shut down the Khaches' shops, the government now attempted to extract as much of the Khaches' wealth, property, and assets as possible. The Barkor Khache were prevented from normal exchange or sale of goods with India, and even ordered to pay, retroactively, six months of sales tax set at an inflated rate (IMEA 1960 IV, 67). Personal accounts described the Lhasa Muslims as living "in constant terror" and "constant fear of being deported or even executed." Others described how "living conditions were very difficult in Lhasa" as a result of the fact that rations had been "fixed at ten kilos of cereals a month and one or two pounds of meat every two months" (Times of India 1960c).

Then, just as suddenly, on September 23, 1960, after nine months of assiduously avoiding any mention of the Khache in communications with Indian officials (and in spite of repeated requests from their Indian counterparts), the Chinese Ministry of Foreign Affairs delivered a succinct four-point diplomatic memo to the Indian Ambassador in Beijing. The memo characterized the yearlong deadlock over the Khache as a misunderstanding entirely of India's own making. It asserted that "the Indian Government repeatedly ignored and distorted the theses of the Chinese government, flagrantly rejected the proposal for a sensible and rational settlement of the question of the nationality of the [Khaches]" (IMEA 1960 IV, 73). It then insisted that while the Khache have always been treated as Chinese, the "Chinese Government would naturally respect the wishes of the concerned [Khaches] who do not want to remain Chinese." The note went on to suggest that "should they, out of their own will, apply to the Chinese Government for exit or ask to settle their nationality, the Ministry of Foreign Affairs believes that the Chinese Government, in view of the friendship between the Chinese and Indian people, will as before effect a sensible and rational settlement of their questions, and will be prepared to give whatever possible consideration to those who apply for exit" (IMEA 1960 IV, 73). The only caveat to this concession was that the Chinese would not release the five Khache leaders who had "committed offenses against the law" (IMEA $1960 \mathrm{IV}, 74$ ). In essence, in the face of mounting international pressure, the Chinese government had decided it was better to concede to the Barkor Tibetans' claim of Indian nationality than to a prolonged diplomatic battle.

Within several days' time, S. L. Chhibbers's replacement, Indian Consul-General P. N. Kaul, quickly drew up a list of the Barkor Khache, and issued identification cards with his seal and signature. By October 1, the first of several hundred Barkor Khache families were transported by Chinese military trucks to Nathula Pass (the border of still-independent Sikkim), where they were met by Indian transport and eventually relocated to the Himalayan hill town of Kalimpong. Over the course of the next six months, nearly 1,000 men, women, and children left Tibet, virtually emptying the Barkor Tibetan Muslim community from Lhasa, Shigatse, and all central Tibetan urban centers (Chen Bo 
2003, 56; Times of India 1960a, 1960d). Only the five Khache from the Khache Council who were sentenced remained behind-with all but one eventually dying in prison (Times of India 1964).

In a sad coda, during the following summer the nearly 800 Wabaling Khache assailed by the Tibetans for helping the Chinese and insufficiently compensated by the Chinese for their aid in subduing Tibet made a bid to also be allowed to emigrate to India (Chen Bo 2000, 91; Renmin ribao 1964). The Indian consul-general could only advise them to approach the Chinese government with their appeal, which the local government officials rejected out of hand. Desperate to elicit a positive response to their request, many Wabaling Khache resigned their positions, refused their ration cards, and moved north of Lhasa to a Muslim cemetery in Dokde, where they pitched their tents and began a campaign of passive resistance. Local officials showing some compassion labeled their actions simply as a "contradiction amongst the masses" rather than the much more severe designation as "enemies of the state." Almost a year later, in what became known as the Lhasa Muslim Incident of 1961 (Tib. hürik kyi nyokdra), the government's patience came to an end. Officials arrested and detained more than a dozen individuals and threatened the use of military force to coerce the remaining families back into the city. In the end, without food, deprived of income and forced to beg to stave off starvation, they slowly returned in ones and twos to their homes, destitute and defeated (Abu Bakr and Sharma 2004, 85; Chen Bo 2000, 91; Khétsun and Akester 2008, 150-51). ${ }^{8}$

\section{CONCLUSION}

If the departure of the Barkor Khache from China as "Kashmiri" suggested a return to their past as Kashmiris, it also forced them to confront their future as Indians. Just days after their arrival, the president of the Indian Tibetan Welfare Association, Faizullah Chisti, received a letter from the Dalai Lama expressing his concern over the "intolerable suppression and endless torture" the Khache had suffered after his departure and urging them to join the Tibetans in India to free Tibet from China and "to make other peaceloving countries of the world better understand our case" (TMRA, November 19, 1960). But within a short period after their arrival, almost all the Tibetan Muslims were granted Indian citizenship quite distinct from the Tibetan Buddhists who remained, permanently, temporary residents of India. The two Tibetan communities maintained cordial relations, but their divergent statuses in India created an unmistakable divide. No offer was extended then or in the future for the Khache to join the other Tibetans in Dharamsala or later in 1963 to play an active role in the Central Tibetan Administration (though several individual Tibetan Muslims were active in Dharamsala). Arriving as Kashmiris and thus, eventually, as Indian citizens, their experience immediately diverged from that of their Tibetan Buddhist compatriots.

\footnotetext{
${ }^{8}$ In a groundbreaking article on the Tibetan Muslims, Chen Bo $(2000,91)$ concludes that if one includes all people whose participation would later have them labeled as "traitors to the state" (panguo jituan) or other political campaigns of the next several years, over fifty-six individuals were negatively affected. Tubten Khétsun suggests that several of those who were imprisoned were executed in 1970 during the "One Smash and Three Antis" campaign (Khétsun and Akester 2008, 151).
} 
United in their desire to leave Lhasa, the Khache were divided over where they should settle. Some among them implored the group to remain in the Himalayan hill towns of Darjeeling and Kalimpong (an area that was familiar to many of them from generations of trade); some exhorted their brethren to "return" to Kashmir (their ostensible homeland); and yet others urged settlement in Saudi Arabia (as the birthplace of Islam). In a spirited two-day meeting with the heads of the families, a majority decided to move to Srinagar in Kashmir, with only several dozen families choosing to remain in Kalimpong and Darjeeling or attempting to emigrate to the Middle East (TMRA, November 18-19, 1960).

The Khaches' arrival in Srinagar was far from idyllic. They endured the first winter in a tent city awaiting the construction of forty two-bedroom apartments to house no fewer than 120 families. The adjustment was difficult. Even though the Tibetan Muslims who emigrated from Tibet eventually all received Indian citizenship, they were prevented from receiving "permanent resident" status in Jammu and Kashmir, due to Kashmir's strict constitutional prerequisites regarding residency established in 1952. A decade and a half after arriving, most Tibetan Muslims lacked employment, were deprived of access to higher education, and remained in substandard housing. One Tibetan Muslim living in Srinagar in the 1970s described their community as having "succumbed to grave poverty, neither coping with, nor maintaining any presentable standard of living, managing on a level that is far below subsistence. Our deterioration of funds have led to a concomitant deterioration of livelihood, education and house" (Tibetan Review 1976, 16). Nor has the situation improved today. In recent fieldwork, Adfar Rashid Shah (2012, 62) remarked that the Khache in Srinagar still are denied Kashmiri permanent resident status (and all the basic benefits that would grant them), cling to their Tibetan identity, and are generally socially isolated from Kashmiri society.

The Tibetan Buddhists who followed the Dalai Lama to India also faced numerous hardships. Yet their situation differed substantially from that of the Tibetan Muslims. Due to a variety of economic and political factors, the exiled Tibetan Buddhists became increasingly dependent on Indian and Western support, and thus often found themselves compelled to play to Western romanticized ideas of Tibetan Buddhism. Tibetan Muslims, though, escaped the double-edged fate of the Tibetans-in-exile community who successfully fled Tibet only to become, in the words of Donald Lopez (1999), "prisoners of Shangri-la." The Tibetan Muslims, on the other hand, by participating in the Indian government's political artifices in its negotiations with China, earned Indian citizenship but quickly lost, in the face of this new popular globalized version of Tibet, any claim to being Tibetan.

The Tibetan Muslims hold an awkward position within the Tibetan exile community. As Carole McGranahan (2010, 16-17) has deftly articulated, "in exile Tibet, a nationalist identity both flourishes and flattens. The perceived need for internal cohesion, given the current political state of Tibet, resulted in the devaluing of diversity in the exile community." This is not to say that the Tibetan Muslims who fled Tibet in 1960 are entirely ignored by the exile community. The Fourteenth Dalai Lama has always had a close relationship with the Tibetan Muslims and has energetically used his popularity as a platform to advocate on their behalf. On his repeated visits to Kashmir over the decades since 1959, he has consistently sought to raise awareness of the Khache community's plight both among other Tibetans and in India more broadly. Equally, the Tibetan 
Muslims continue to accord him a high level of respect. When asked, during the Dalai Lama's latest visit to Kashmir in 2012, why Tibetan Muslims supported his visit, one Tibetan Muslim replied, "his Holiness, the Dalai Lama, is our king, our leader. We all love him. That is why we are here" (Raina 2012). The Khaches' continued reverence for the Dalai Lama accentuates his traditional secular role as a leader for all Tibetans regardless of religious orientation.

Curiously, the 1960 Tibetan Muslim Incident shares another linkage with the Sino-Indonesian Crisis of 1959-60. China's intervention in Indonesia during 1959 and 1960 played heavily on the victimization of the Chinese, thus suggesting that it was Indonesia, not China, that was deviating from the ethos of the Bandung Conference. The power and forcefulness of that Chinese assertion remained potent enough so that when India leveraged China's victimization strategy against it to break the stalemate over the Lhasa Khache, China had no effective response. The Khache who immigrated to India and the “returned overseas Chinese” (Ch. guiguo huaqiao 归国华侨) retain highly nostalgic memories of their adopted homelands. Like the returned overseas Chinese who discovered, upon their return to China, that they had in fact become more Indonesian than they realized (as was repeatedly pointed out to them by native Chinese), the Khache discovered that they had little in common with the Kashmiri who resisted their inclusion in Kashmiri society. In both cases, the national governments that had orchestrated their return quickly lost their initial enthusiasm as the political value of such actions diminished (Godley 1989; Tan 2010).

But similar to the ways in which the Bandung Conference is often dismissed as having largely achieved only symbolic outcomes, the 1960 Tibetan Muslim Incident, when remembered, is often cast as subsidiary to more substantive Sino-Indian crises. Framed in this manner, the history of Tibetan Muslims reveals how ethnic, religious, and political categories of postcolonial Asian nationhood often conceal significant dimensions of Asia's past. The Khaches' experiences in the post-independence period bring into sharp relief those-often minority peoples—who reside in regions that fall outside both the colonial and nation-states normative territorialization of Asia. Even the oddly oxymoronic sensation of the ethnonym "Tibetan Muslims" points to the tremendous pressures the Khache resist to retain an identity, which within pre-1959 Tibet had prevailed for centuries. Inherently transnational, translocal, and transcultural, the Barkor Khache, by simply stepping across the political border of Tibet into India, had their existing South Asian narrative of community rewritten in a manner that repositioned them. In these complex and highly politicized post-partition ethnic, subnational, and religious identities, they found none that could accommodate the Tibetan dimension of their identity (Larson 2014). Stripped of their hybrid Tibetan identity, excluded from any formal position in the government-in-exile that emerged in Dharamsala, and shunned in Kashmir, the Khache became exiles manqué-recognized neither by the land they had left nor by the "homeland" to which they had fled.

\section{Acknowledgments}

The research for this project would not have been possible without the generous support of an Andrew W. Mellon Foundation New Directions Grant. The article is 
much improved as a result of Jeff Wasserstrom's able selection of five anonymous reviewers not only whose comments made this article factually more accurate but whose generous and numerous suggestions to the original draft have made the final article more intelligible to scholars across multiple disciplines and regional concentrations. I am grateful to Arye Chakravartty, who challenged me at every stage to understand the nuances of Himalayan Asia, and to Michael Kulikowski, who repeatedly urged me to finish. Special thanks to Zhang Zhongyun and Tsomu Yudru. Finally, Amanullah Chisti and Abdul Rehman Khallo deserve special mention for spending many hours patiently and generously sharing their knowledge of the Khache community. I hope they find some merit in what I have written here.

\section{List of References}

Aвraham, Iтty. 2008. "Bandung and State Formation in Post-colonial Asia." In Bandung Revisited: The Legacy of the 1955 Asian-African Conference for International Order, eds. See Seng Tan and Amitav Acharya, 48-67. Singapore: National University of Singapore Press.

Abū Bakr Amirudīin Tibbatì Nadvī and Parmananda Sharma, trans. 2004. Tibet and Tibetan Muslims. Dharamsala: Library of Tibetan Works and Archives.

Akasoy, Anna, Charles Burnett, and Ronit Yoeli-Tlalim, eds. 2010. Islam and Tibet: Interactions along the Musk Routes. Farnham, England: Ashgate.

Altner, Diana. 2010. "Do All the Muslims of Tibet Belong to the Hui Nationality?" In Islam and Tibet: Interactions along the Musk Routes, eds. Anna Akasoy, Charles Burnett, and Ronit Yoeli-Tlalim, 339-52. Farnham, England: Ashgate.

Anand, Dibyesh. 2009. "Strategic Hypocrisy: The British Imperial Scripting of Tibet's Geopolitical Identity.” Journal of Asian Studies 68(1):227-52.

Arnold, Thomas W. 1913. The Preaching of Islam: A History of the Propagation of the Muslim Faith. London: Constable \& Company.

Beckwith, Christopher. 1989. "The Location and Population of Tibet According to Early Islamic Sources.” Acta Orientalia Academiae 43(2/3):163-70.

Boulnois, Luce. 1983. Poudre d'or et monnaies d'argent au Tibet (principalement au XVIIIe siècle) [Powdered gold and silver coins in Tibet (principally in the eighteenth century)]. Paris: Editions du Centre National de la Recherche Scientifique.

Bray, John. 2012. "Readings on Islam in Ladakh: Local, Regional and International Perspectives." Himalaya, the Journal of the Association for Nepal and Himalayan Studies 32(1):13-21.

Broomhall, Marshall. 1910. Islam in China: A Neglected Problem. London: Morgan \& Scott.

Cabezón, José Ignacio. 1998. "Islam on the Roof of the World.” Saudi Aramco World 49 $(1): 12-23$.

- 2010. Tibetan Ritual. Oxford: Oxford University Press.

Chapman, F. Spencer. 1938. Lhasa, the Holy City. London: Chatto \& Windus.

Chen Bo. 2000. "Lasa Musulin qunti diaocha" [Investigation of Lhasa Muslims]. Xibei minzu yanjiu 1:87-94.

—. 2003. "A Multicultural Interpretation of an Ethnic Muslim Minority: The Case of the Hui Tibetan in Lhasa." Journal of Muslim Minority Affairs 23(1):41-61.

Chen Jian. 2006. "The Tibetan Rebellion of 1959 and China's Changing Relations with India and the Soviet Union.” Journal of Cold War Studies 8(3):54-101. 
Chen Zonglie. 2009. "Baguojie” [Barkor Street]. Xizang lüyou zazhi 94(10):18-21.

Ciduo. 1992. "Lasa Huimin.” Xizang wenxue 1:110-19.

Das, Sarat Chandra. [1902] 1970. Journey to Lhasa and Central Tibet. New Delhi: Mañjusri Publishing House.

Dastider, Mollica. 2007. Understanding Nepal: Muslims in a Plural Society. New Delhi: Har-Anand Publications.

Dawa Norbu. 1992. "Otherness and the Modern Tibetan Identity." Himāl 5(3):10-11.

—. 1997. "Tibet in Sino-Indian Relations: The Centrality of Marginality." Asian Survey 37(11):1078-95.

Desideri, Ippolito, Michael J. Sweet, and Leonard Zwilling. 2010. Mission to Tibet: The Extraordinary Eighteenth-Century Account of Father Ippolito Desideri, S.J. Boston: Wisdom Publications.

Dorjee, Tenzin, and Howard Giles. 2005. "Cultural Identity in Tibetan Diasporas." Journal of Multilingual and Multicultural Development 26(2):138-57.

Ekvall, Robert B. 1960. “The Tibetan Self-Image.” Pacific Affairs 33(4):375-82.

FANG JiAnCHANG. 1992. "Xizang Huizu yu qingzhensi yanjiu de ruogan wenti” [An examination of the number of Tibetan Hui and mosques]. Huizu yanjiu 2:27-30.

FBis (Foreign Broadcast Information Service). 1959a. "Corban Observed." June 19: FRB-59-122.

1959b. “CPR Interference in Indonesia Scored.” December 30: FRB-59-254.

1959c. "Speakers Denounce Rebels.” April 16: FRB-59-074.

Fischer, Andrew Martin. 2008. "The Muslim Cook, the Tibetan Client, His Lama, and Their Boycott: Modern Religious Discourses of Anti-Muslim Economic Activism in Amdo." In Conflict and Social Order in Tibet and Inner Asia, eds. Fernanda Pirie and Toni Huber, 159-92. Leiden: Brill.

French, Rebecca Redwood. 2002. The Golden Yoke: The Legal Cosmology of Buddhist Tibet. Ithaca, N.Y.: Cornell University Press.

Gaborieau, Marc. 1995. "Powers and Authority of Sufis among the Kashmiri Muslims in Tibet." Tibet Journal 20(3):21-31.

Gaborieau, Marc, and Khwājah Ghulām Muhammad. 1973. Récit d’un voyageur Musulman au Tibet [Story of a Muslim traveler in Tibet]. Paris: Klincksieck.

Gellner, David N. 1992. Monk, Householder, and Tantric Priest: Newar Buddhism and Its Hierarchy of Ritual. Cambridge: Cambridge University Press.

Godley, Michael R. 1989. “The Sojourners: Returned Overseas Chinese in the People's Republic of China.” Pacific Affairs 62(3):330-52.

Goldstein, Melvyn C. 1997. The Snow Lion and the Dragon: China, Tibet, and the Dalai Lama. Berkeley: University of California Press.

— 2007. A History of Modern Tibet, Volume 2: The Calm Before the Storm, 19511955. Berkeley: University of California Press.

— 2013. A History of Modern Tibet, Volume 3: The Storm Clouds Descend, 19551957. Berkeley: University of California Press.

Goldstein, Melvyn C., Dawei Sherap, and William R. Siebenschuh. 2004. A Tibetan Revolutionary: The Political Life and Times of Bapa Phüntso Wangye. Berkeley: University of California Press.

Gopal, Sarvepaldi. 1976. Jawaharlal Nehru: A Biography (Volume Three, 1956-1964). Cambridge, Mass.: Harvard University Press.

Green, Nile. 2013. "Forgotten Futures: Indian Muslims in the Trans-Islamic Turn to Japan.” Journal of Asian Studies 72(3):611-31. 
Gupta, AкнiL. 1992. "The Song of the Nonaligned World: Transnational Identities and the Reinscription of Space in Late Capitalism.” Cultural Anthropology 7(1):63-79.

Harrer, Heinrich. 1954. Seven Years in Tibet. New York: Dutton.

Harris, Tina. 2013. Geographical Diversions: Tibetan Trade, Global Transactions. Athens: University of Georgia Press.

Henrr, Gray, Abdul Wahid Radhu, Marco Pallis, and Jane Casewit. 1997. Islam in Tibet. Louisville, Ky.: Fons Vitae.

Horlemann, Bianca. 2012. "Tibetans and Muslims in Northwest China: Economic and Political Aspects of a Complex Historical Relationship.” Asian Highlands Perspectives 21:141-86.

Huc, Evariste Régis, and H. D’ Ardenne de Tizac. [1850] 1925. Souvenirs d'un voyage dans la Tartarie, le Thibet et la Chine [Memories of a journey in Tartary, Tibet and China]. 2 vols. Paris: Plon-Nourrit et cie.

IMEA (India Ministry of External Affairs). 1959-68. Notes, Memoranda and Letters Exchanged and Agreements Signed between the Governments of India and China: White Paper. Vols. 1-14. [New Delhi]: Ministry of External Affairs.

JiaO YInGQI. [1721] 1966. Xizang zhi [Gazetteer of Tibet]. Taipei: Wenhai chubanshe.

Kahin, George M. T. 1956. The Asian-African Conference, Bandung, Indonesia, April 1955. Ithaca, N.Y.: Cornell University Press.

Kaul, Prem Nath. 1976. Frontier Callings. Delhi: Vikkas Publishing House.

Kennedy, Andrew Bingham. 2012. The International Ambitions of Mao and Nehru: National Efficacy Beliefs and the Making of Foreign Policy. New York: Cambridge University Press.

Khatchikian, Levon. 1996. "The Ledger of the Merchant Hovhannes Joughayetsi." In Merchant Networks in the Early Modern World, ed. Sanjay Subrahmanyam, 12559. Aldershot, England: Variorum.

Khétsun, Tubten, and Matthew Akester. 2008. Memories of Life in Lhasa under Chinese Rule. New York: Columbia University Press.

Larson, Gerald James. 2014. "Partition: The 'Pulsing Heart that Grieved." Journal of Asian Studies 73(1):5-8.

Lee, Christopher J. 2010. "Between a Moment and an Era: The Origins and Afterlives of Bandung." In Making a World after Empire: The Bandung Moment and Its Political Afterlives, ed. Christopher J. Lee, 1-44. Athens: Ohio University Press.

Li Hongchun. 2006. "Xianwei renzhi de Yunnan 'Zang-Hui." [The unknown Yunnan Tibetan Muslims]. Zhongguo Musilin 1:44-47.

Liu, Xuecheng. 1994. The Sino-Indian Border Dispute and Sino-Indian Relations. Lanham, Md.: University Press of America.

Lopez, Donald S. 1999. Prisoners of Shangri-La: Tibetan Buddhism and the West. Chicago: University of Chicago Press.

Ma Jianye. 1947. "Xizang Lasa de Huimin” [Muslims of Lhasa Tibet]. Huijiao qingnian yuebao 32:12.

Ma Rongjiu. 2014. "Domestic Politics and India's Foreign Policy Making in the Sino-Indian Territorial Dispute (1959-1962).” Journal of Asian Public Policy 7(1): 102-13.

Macdonald, David. 1932. Twenty Years in Tibet: Intimate and Personal Experiences of the Closed Land among All Classes of Its People from the Highest to the Lowest. London: Seeley, Service.

Mackie, J. A. C. 1976. “Anti-Chinese Outbreaks in Indonesia, 1959-68.” In The Chinese in Indonesia, ed. J. A. C. Mackie, 115-28. Honolulu: University Press of Hawai'i. 
McGranahan, Carole. 2010. Arrested Histories: Tibet, the CIA, and Memories of a Forgotten War. Durham, N.C.: Duke University Press.

Meng BaO. [1852] 1978. Xizang zoushu [Memorials on Tibet]. Taipei: Guangwen shuju.

Minorsky, Vladimir, V. V. Bartol D, and Clifford Edmund Bosworth. 1970. Hudūd al- Ālam; The Regions of the World; a Persian Geography, 372 A.H.-982 A.D. London: Luzac.

Mozingo, David P. 2007. Chinese Policy Toward Indonesia, 1949-1967. Ithaca, N.Y.: Cornell University Press.

NaIK, Yusuf. 1995. "Memories of My Father, Abdul Ghani, in Tibet.” Tibet Journal 20(3): $31-35$

Nehru, Jawaharlal. 1984. "Policy Regarding China and Tibet (18 November 1950)." In Selected Works of Jawaharlal Nehru Second Series, ed. S. Gopal, vol. 14, pt. 2, 34246. New Delhi: Jawaharlal Nehru Memorial Fund, distributed by Oxford University Press.

Newman, John. 1998. "Islam in the Kālacakra.” Journal of the International Association of Buddhist Studies 21(2):311-72.

New York Times. 1959. “India’s Traders Held by Chinese: New Delhi Says Reds Detain Five in Tibet and Prevent Hundreds from Returning." August 12, 2.

Ortner, Sherry B. 1989. High Religion: A Cultural and Political History of Sherpa Buddhism. Princeton, N.J.: Princeton University Press.

Pelliot, Paul. 1947. "Le ōj a et le Sayyid Husain de l'histoire des Ming" [The ōj a and Sayyid Husain in Ming history]. T'oung Pao 38(1-2):81-292.

Peter, Prince of Greece. 1951. "The Moslems of Central Tibet.” Asian Affairs 39(3-4): $232-40$.

Pollock, SHeldon. 2011. Forms of Knowledge in Early Modern Asia: Explorations in the Intellectual History of India and Tibet, 1500-1800. Durham, N.C.: Duke University Press.

Pomplun, Trent. 2010. Jesuit on the Roof of the World: Ippolito Desideri's Mission to Eighteenth-Century Tibet. New York: Oxford University Press.

Powers, John, and David Templeman. 2012. Historical Dictionary of Tibet. Lanham, Md.: Scarecrow Press.

Radhu, Abdul Wahid. 1997. Islam in Tibet: [and] Tibetan Caravans. Louisville, Ky.: Fons Vitae.

Rahul, R. 1961. "Kashmiri Muslims in Tibet.” International Studies 3(2):181-83.

Raina, Muzzaffar. 2012. "Dalai Lama Thrills a Corner of Kashmir.” Telegraph (India), July 15. http://www.telegraphindia.com/1120715/jsp/nation/story_15730816.jsp (accessed March 7, 2014).

Rajesh, M. N. 2005. "Islam on the Periphery: A Case Study of Tibetan Muslims." In Approaching Islam, ed. Rattanlal Hangloo, 203-14. New Delhi: Black and White.

Ramble, Charles. 1993. "Whither, Indeed, the Tsampa Eaters." Himāl 6(5):21-25.

RENMIN RIBAO. 1959a. "Huanhu zhengfu wei xizang rennin chuhai; Qingzhu xizang renmin zouxiang xinsheng, Xizang renmin relie yonghu taoping panni" [Hail the government for removing the Tibetan people from harm's way; Celebrate the Tibetan people's moving towards a new life; The Tibetan people fervently endorse the suppression of the rebels]. April 2, 1.

. 1959b. "Miejue renxing lingren fazhi, Xizang panfei waxin sharen zui'e taotian" [Inhuman! Deplorable! Tibetan rebels heinously murder by ripping out hearts]. April 26, 4. 
. 1959c. "Xizang panfei de 'Weijiao Jun'-yiguan qinshou he pizhe jiasha de chailang" [Tibetan rebels "Protect Religion Army"-Animals dressed in nice clothes; Wolves wearing monk's robes]. May 5, 2.

. 1959d. "Xizang panguo jituan biran miewang; Xizang rennin qiantu guangming canlan; Jiefang jun yi xunsu pingding lasa panluan; Zai sengsu gejie aiguo renmin xiezhu xia; Zheng chengsheng qianjin saodang xizang qita difang de panfei" [The traitorous Tibetan clique is certain to be exterminated; The future of Tibet's people is bright and glorious; PLA swiftly pacifies Lhasa armed rebellion, and with help from clergy and lay patriots, mop up Tibetan traitorous elements in other areas]. March 29, 1.

1959e. "Xizang rennin yongyuan zhongyu zuguo; Lasa liang wan ren kongqian da shiwei; Zai budalagong qian renmen fenfen kongsu panfei de taotian zuixing [The Tibetan people are forever loyal to the homeland; An unprecedented twenty thousand people hold rally in Lhasa; In front of the Potala Palace people one after the other denounce the rebels' monstrous crimes]. April 16, 1-2.

. 1964. "Beijing Lasa musilin huandu kaizhaijie" [Beijing and Lhasa Muslims celebrate Eid al-Fitr]. February 2, 2.

Richardson, Hugh. 1984. Tibet and Its History. Boston: Shambhala.

Rockhill, William W. 1891. The Land of the Lamas: Notes of a Journey through China, Mongolia and Tibet with Maps and Illustrations. New York: Century.

SAmuel, Geoffrey. 1976. "Songs of Lhasa." Ethnomusicology 20(3):407-49.

. 1993. Civilized Shamans: Buddhism in Tibetan Societies. Washington, D.C.: Smithsonian Institution Press.

Sandberg, Graham. 1906. Tibet and the Tibetans. London: Society for Promoting Christian Knowledge.

Shah, Adfar Rashid. 2012. "Exploring Ethnicities: A Socio-Cultural Profile of Tibetan Community in Indian Kashmir." Tibet Journal 37(3):47-70.

Shakya, Tsering. 1993. "Whither the Tsampa Eater." Himāl 6(5):8-11.

- 1999. Dragon in the Land of Snow: A History of Modern Tibet since 1947. New York: Columbia University Press.

Siddiqui, Ataullah. 1991. "Muslims of Tibet." Tibet Journal 14(4):71-85.

Suo QIong. 2002. "Fofa shengdi de yisilan wenming” [Islamic culture in a Buddhist sacred land]. Xizang minsu 4:55-61.

Tan Chee-Beng. 2010. "Reterritorialization of a Balinese Chinese Community in Quanzhou, Fujian.” Modern Asian Studies 44(3):547-66.

Tan, Gillian. 2013. "An Ethnography of Life and Changes among Tibetan Nomads of Minyag Dora Karmo, Ganzi Tibetan Autonomous Prefecture, Sichuan Province.” Études Mongoles et Sibériennes, Centrasiatiques et Tibétaines, 43-44. http:// emscat.revues.org/2111 (accessed May 17, 2014).

Tan, See Seng, and Amitave Acharaya. 2008. "Introduction.” In Bandung Revisited: The Legacy of the 1955 Asian-African Conference for International Order, eds. See Seng Tan and Amitave Acharaya, 1-16. Singapore: National University of Singapore Press.

Tibetan Review. 1976. "Tibetan Refugees in Kashmir.” May, 15-17.

Times of India. 1959. "Five Indians Held in Custody by Chinese." September 8, 3.

_. 1960a. "Kashmiri Muslim Families Return." November 16, 1.

—. 1960b. "Plea on Kashmiri Muslims in Tibet Rejected by China." February 27, 1.

—. 1960c. "Red Terror in Tibet: Nepalese Muslims’ Experience." August 6, 1.

—. 1960d. "Tibetan Refugees for Sikkim." October 1, 7.

—. 1964. "5 Indian Muslims Held in Tibet." February 18, 5. 
TMRA (Tibetan Muslim Refugee Association). 1959-69. Fazulla Chisti Personal Papers.

Tsarong, Dundul Namgyal, and Trinlay Chödron. 2000. In the Service of His Country: The Biography of Dasang Damdul Tsarong, Commander General of Tibet. Ithaca, N. Y.: Snow Lion Publications.

Tshe RDOR. 1992. "Lha sa'i kha che" [Lhasa khache]. Bod kyi rtsom rig sgyu rtsal 4:11228.

Tsing, Anna Lowenhaupt. 2009. “Adat/Indigenous: Indigeneity in Motion.” In Words in Motion: Toward a Global Lexicon, eds. Carol Gluck and Anna Lowenhaupt Tsing, 40-64. Durham, N.C.: Duke University Press.

Vasantkumar, Chris. 2012. "What Is This 'Chinese’ in Overseas Chinese? Sojourn Work and the Place of China's Minority Nationalities in Extraterritorial Chinese-ness." Journal of Asian Studies 71(2):423-46.

WADDle, L. Austine. 1905. Lhasa and Its Mysteries with a Record of the Expedition of 1903 to 1904. London: Methuen \& Company.

Wenqing, Zhen Jia, and Baoyun, eds. [1930] 1963. Chouban yiwu shimo [The complete record on managing foreign affairs]. Taipei: Guofeng chubanshe.

Wu Fengpei and Songyun. [1721] 1982. Xizang zhi Weizang Tongzhi [Gazetteer of Tibet]. Lhasa: Xizang renmin chubanshe.

Xinhua News Agency. 1968. "Communiqué on the Revolt, March 28, 1959." In Tibet: 1950-1967, ed. Nai-min Ling, 350-51. Hong Kong: Union Research Institute.

XIZANG Ribao [Tibet Daily]. [1957] 1968. [Untitled, December 27, 1957]. In Tibet, 1950 1967, ed. Nai-min Ling, 520. Hong Kong: Union Research Institute.

Xu Chengcang. 2007. Lasa shi zhi [Gazetteer of Lhasa City]. Vol 2. Beijing: Zhongguo Zangxue chubanshe.

Xue Wenbo. 1986. "Lasa de Huizu” [Lhasa’s Hui]. Gansu minzu yanjiu 2:68-76.

Yang FangCan. [1816] 1967. Sichuan tongzhi [Gazetteer of Sichuan]. Taipei: Huawen shuju.

Yen, EmiLy. 2007. “Tibetan Indigeneity: Translations, Resemblances, and Uptake.” In Indigenous Experience Today, eds. Marisol de la Cadena and Orin Starn, 69-98. Oxford: Berg.

. 2009. "Living Together in Lhasa: Ethnic Relations, Coercive Amity and Subaltern Cosmopolitanism.” In The Other Global City, ed. Shail Mayaram, 54-85. New York: Routledge.

Yıwu. 1946. "Xizang Huimin" [Tibet's Hui]. Yuehua 16(4-6):12.

Zhang Chunxiu. 2002. "Lasa de Qingzhensi he musilin mudi" [Mosques and Muslim cemeteries of Lhasa]. Zhongguo Musilin 1:27-28.

ZhongGuo Yisilanjiao xiehui [An overview of Islam in China]. 2011. Beijing: Zongjiao cenhua chubanshe. 